\title{
THE IMPACT OF SOCIAL AND ECONOMIC FACTORS IN THE CREDIT RISK MANAGEMENT OF SME
}

\author{
Jaroslav BELAS ${ }^{1}$, Lubos SMRCKA ${ }^{2}$, Beata GAVUROVA ${ }^{3 \star}$, Jan DVORSKY ${ }^{4}$ \\ 1, ${ }^{4}$ Department of Enterprise Economics, Faculty of Management and Economics, \\ Thomas Bata University, Zlin, Czech Republic \\ ${ }^{2}$ Department of Strategy, Faculty of Business Administration, University of Economics Prague, \\ Prague, Czech Republic \\ ${ }^{3}$ Department of Banking and Investment, Faculty of Economics, \\ Technical University of Košice, Němcovej 32, 04001 Košice, Slovakia
}

Received 11 June 2017; accepted 27 August 2017

\begin{abstract}
Numerous research studies deal with the issue of researching the impacts on credit risk determinants in the SME segment. The study of economic factors that are easier to quantify from methodological point of view, and which prevent complex evaluation of causality of interest rate risk and the discovery of various social barriers dominate. This consistent fact forms a platform in designing the research to introduce a model of dependency of effective credit risk management in the SME segment on significant social and economic factors. Empirical research was carried out in the Czech business environment in 2017 on a sample of 352 enterprises. The structural analysis modeling (SEM) was the main analytical method. The research results confirmed the fact that an effective approach to managing the SME's credit risk is determined by a number of factors of a non-economic nature. The most important are education and family environment. These are followed by economic factors, such as a relationship with banks, financial knowledge in the area of capital and payment discipline. The multi-spectral dimension of the findings and causality also opened up a wide discussion and prepared a high-quality data research base for further deeper exploration of this issue.
\end{abstract}

Keywords: small and medium-sized enterprises, SME, credit risk, social factor, economic factor, credit risk management, Czech Republic.

JEL Classification: G32, L26, L53.

\section{Introduction}

Management of credit risk and financing difficulties encountered by the small and medium enterprises (SME) are highly debatable topics in the area of entrepreneurial finance for decades. However, the topics are still interesting for the academic researcher due to information opacity related to SME financing. It is disputable that SME represent opaque information and

*Corresponding author. E-mail: beata.gavurova@tuke.sk

This is an Open Access article distributed under the terms of the Creative Commons Attribution License (http://creativecommons. org/licenses/by/4.0/), which permits unrestricted use, distribution, and reproduction in any medium, provided the original author and source are credited. 
due to this fact, it is difficult for the lenders to evaluate the credit risk of the borrowers (Beck, Degryse, De Haas, \& Van Horen, 2015).

Empirical research shows that due to global financial crisis, it is getting even more difficult for the SME to get bank finance and which is questioning the survival of the SME (Kremp \& Sevestre, 2013). As the financial crisis banks are reluctant to lend to information opaque small businesses and hence, the SME face difficulties to maintain their financial position. Therefore, financial risk is increasing for the SME due to lack of suitable sources of external finance. On the other hand, Dierkes, Erner, Langer, and Norden (2013) found out that default rate of the SME are higher than the large companies since they are prone to excessive competition from the large companies and their profitability largely depends on the proper utilization of financial resources. Hence, better credit management system may help the SME to overcome default rates and also they can access bank credit more frequently and with ease.

This paper examines the financial and non-financial determinants of credit risk for the SME in the context of the Czech Republic. The Czech Republic is a bank based economy and hence the SME are highly dependent on the banks to get external funding (Kozubíkova, Belas, Bilan, \& Bartos, 2015). The SME are the integral part of the economic system of the Czech Republic where $99.8 \%$ of the businesses are in the SME segment. Thus, finding the determinants of credit risk for the SME can be a significant contribution in the SME financing literature as it can foster the knowledge of the entrepreneurs to know about the factors that may affect the credit risk and also how they can get easy access to finance from the bank. Although, SME present a significant economic force as a group, they are extremely vulnerable as single entities. It is necessary to understand that the vast majority of the SME $(92.8 \%$ of all ventures) are micro enterprises with less than 10 employees in order to realize the extent of their susceptibility (European Commission, 2016). They are usually underfinanced and extremely susceptible to the social, legal and business environment. According to the Small Business Act Fact Sheet, the greatest weaknesses of the SME are the Skills \& Innovation field and the State \& Public Procurement field, while the lack of sufficient entrepreneurship, the prevailing single market approach, and the still problematic access to finance are also major contributors when it comes to business failures (European Union, 2016).

The excellence of the research lies in the construction of a comprehensive model of entrepreneurial attitude in the SME segment of credit risk, which is an extremely important area of management for each company. The model focuses not only on economic, but also social factors, together with chosen personalities of entrepreneurs.

The structure of the contribution is as follows. The introductory part consists of a research study that outlined the picture of several dimensions of research in the area of risk management in the SME segment presented by researchers in different countries. Its content and process structure has been chosen to highlight the importance of addressing this issue in the Czech Republic. The next part provides a detailed description of empirical research, characteristics of the research sample and complex methodology. In the following analytical part, partial thorough procedures as well as the quantified results are presented which open up the scope for the evaluation of the results and their discussion. At the end of the discussion, the usefulness of research results for subsequent research as well as practice is presented. 


\section{Theoretical background}

Credit risk research is an integral part of any credit process in financial institutions, and there are evident particularities in the SME lending process. The importance of monitoring and monitoring these processes is becoming increasingly apparent due to the financial crisis and increased capital requirements for banks (Corazza, Funari, \& Gusso, 2016; Yahaya, Mansor, \& Bakar, 2016; Psillaki \& Eleftheriou, 2014). Many research studies addressing this issue have focused on the various processes and determinants affecting the structure and quality of bank institutions' relationships with the SME in order to point the marked heterogeneity and diametrical differences in the relationship between the enterprises and the financial institutions (Fredriksson \& Moro, 2014; Kundid \& Erecgovac, 2011; Neuberger \& Räthke-Döppner, 2014; Beck \& Demirguc-Kunt, 2006).

In the examined studies, the dominant financial processes are easier to quantify and generalize. On the other hand, the discovery of other causal determinants is more difficult (Irwin \& Scott, 2010). In this context, interesting research was conducted in Finland that analyzed 4285 banks and examined their impact on the SME performance and profitability. Loans were an important dimension of this process. The process of their acquisition was determined by the negotiating power of the SME with a strong role played by the strong financial position of the SME (Fredriksson \& Moro, 2014). The Yao Wang study (2016) was primarily focused on analyzing the biggest barriers to the development of the SME from the point of view of corporate managers, based on the World Bank's Enterprise Survey which includes data from 119 developing countries. The SME see access to funds as the most significant obstacle to their growth, with the main barriers to external financing of the SME perceived by managers as: access to financial resources, tax rates, competition, political factors. The study differentiates and quantifies the diametrically different conditions for access to finance in the SME with state support confronted with the private SME. Companies with state support have better access to loans due to the implicit or explicit guarantees from government in relation to government interventions (Mohelska \& Sokolova, 2016; Sokolová, Mohelská, \& Zubr, 2016). The study also shows the imperfection of the financial system in the country due to the asymmetry of information between banks and the SME, the fragmentation of financial markets and the significant high transaction costs. Different approach to this issue may be seen in presenting the results of the research study by Fairlie and Holleran (2012), who highlight the importance of analyzing psychological characteristics in the process of preparing for the entrepreneurship of individuals. The study was conducted as part of the Growing America through Entrepreneurship project. The results of this project clearly declare that individuals who are more tolerant of higher risk are more prosperous from training to business than less risk tolerant individuals. Those ones that also attach considerable weight to the methodological aspects of examining the impact of financial determinants on the SME development were registered. The study by Eggers, Kraus, Hughes, Laraway, and Snycerski (2013), the Austrian authors, uses exploratory factor analysis to evaluate data from research conducted in 2010, with 10000 randomly selected SME (return on questionnaires $6.6 \%$ ). The aim was to identify the impact of customer orientation and business orientation on the SME's growth. The results have shown that sustainable growth of SME is not possible 
without entrepreneurial orientation, and the SME's customer focus is of great importance to their development. Berger and Udell (2006) draw attention to the research of the impact of credit technology on the credit availability process for SMEs, and in particular, the availability of quality data, allowing for segmentation and consequently prioritization of the SME to assess the availability of external resources. Bruns and Fletcher (2008) have tried experimental methods to identify lending officers' probabilities to support emerging or the existing SME. On a sample of 114 Swedish lending officers authors tested the hypothesis constructed on a platform of information available on the debtor and its ability to repay the loan. Also, the degree of risk sharing tested the hypotheses concerning how information on the borrower's ability to repay the loan; alignment of risk preferences; and risk sharing affect their willingness to grant credit. This research explicitly draws attention to the interaction between the factors influencing banks' decision to grant loans to SME, as well as the resulting consequences. The findings from this study clearly state the strong emphasis of banks in providing loans to SME on material accounting indicators and the factors that shift the risk from the bank to the borrower. The risk is determined by the borrower's financial condition and the security available to the borrower. The credit-worthiness of the Italian SME at the outset of the economic crisis is positively mapped in the study by Corazza et al. (2016). A high number - 40000 of the Italian SME were analyzed and the Multi-Criteria Decision Analysis (MCDA) was applied to the data analysis. The authors used a modified version of this analysis - the MURAME methodology applied to credit risk assessment, all of which influenced the company's solvency level. Despite the expectation that the authors will also work on the influence of non-financial factors on the borrower's creditworthiness, the socalled hard data and the results were rather oriented to the early signs of recession in the SME sector in Italy. Estimation of credit risk and its quantification in the SME segment was also discussed by Li, Niskanen, Kolehmainen, and Niskanen (2016). The aim of the study was to present a new, more accurate approach to estimating the credit risk of business loans for SME. The authors suggested a hybrid model that combines the logistic regression approach and artificial neural networks. Data from the Finnish SME from 2004 to 2012 were used for the analysis. The applied model proved to be more accurate in the credit assessment process and eliminated significant errors in the previous processes.

Research studies addressing the issue are characterized by heterogeneity. They are the results of specific research teams, differing in their focus, research objectives, research sample, and methodologies. The systemic complexity of many studies and their conceptual heterogeneity significantly impedes the unification of results, and they can provide an important platform for complementary exploration of the subject, and for the discovery of many contexts, also in the context of changes in external influences in national and international environments. The bulk of research studies dominate the economic factors affecting credit risk in the SME, with the non-economic factors being imported into research structures to a minimum or in implicit forms, or are completely eliminated within the investigated impacts (Grunert, Norden, \& Weber, 2005). Many, so-called non-economic factors, have significant psychological and social links to the individual's behavior and management processes in companies. Explicit examination of their impact on credit risk management in the SME segment in research studies is absent. The reason is mainly the problematic examination of 
the so-called soft factors and the absence of methodologies to detect and quantify the extent of their impact on effective credit risk management. The research platform for these types of data is of a qualitative nature with a marked degree of subjectivism which is necessary to eliminate by applying selected expert methods. Therefore, in research studies, the predominant aspect is above all the age and education of individuals (Sobeková-Majková, 2016; Vos, Yeh, Carter, \& Tagg, 2007), which significantly determine the attitude of the entrepreneur to credit risk and their links are explicit, whether family, social or media. This is also stated in the study by Vos et al. (2007) and Kozubíkova, Homolka, and Kristalas (2017) examining the relationship among age, level of entrepreneurship education and the interest rate of external sources of financing. Younger and less educated entrepreneurs use more external funding for their growth as older and more educated. Similarly, Lazányi (2014) confirms a higher rate of credit risk perception among younger than older entrepreneurs. German experts, Neuberger and Räthke-Döppner (2014), also incorporated into their study the impact of complex demographic indicators and their results also confirm the tendency to pay higher interest rates among young entrepreneurs. This is mainly confronted with the liquidity parameter. The influence of age and education in relation to bank loans in the Slovenian business environment was examined by Slavec (2014), stating that education plays a much more important role in bank loans than the age of entrepreneurs. By confronting the studies that predominantly dominate economic factors as core attributes of credit risk research of the SME entrepreneurs.

A particular research platform, reflecting the significant absence of non-economic determinants in examining entrepreneurial credit risk was set. In the study, education is also considered as a significant element of the system with interactions in the family, social and media environment. While the family environment is interconnected with its impact, it is also influenced by the pre-productive age of the individual, the social and the media with the productive age.

The system of causal relations between credit risk management and social and economic factors is shown in Figure 1 presenting the created model, which forms a complex platform of determinants of an investigation. The hierarchical line within the examined environments, which is declared by the system of one-way as well as the two-way relationships between the factors are not considered. Education is an implicit part of the impact of the family and social environment, and in many lines, it affects the characteristics of the borrower. In view of examining the credit risk in the SME segment, (where the manager often plays the role of the business owner), the main focus is on basic constructs, such as bank relationships, financial knowledge and payment discipline.

The vast majority of authors study credit risk only from the point of view of the bank. Given that both parties the bank (the creditor) and the business (the debtor) are involved in this risk; it is appropriate and beneficial to investigate the risk of failure to manage the loan repayment, or effective risk management by SME. In the context of the explained factors and the links between them, the objective of the contribution was formulated. The main objective is "to construct a causal model examining the relationship between the credit risk factor and its economic and social determinants specific to the SME business environment". This objecive is to quantify the impacts of individual factors on the effective management of credit risk. 


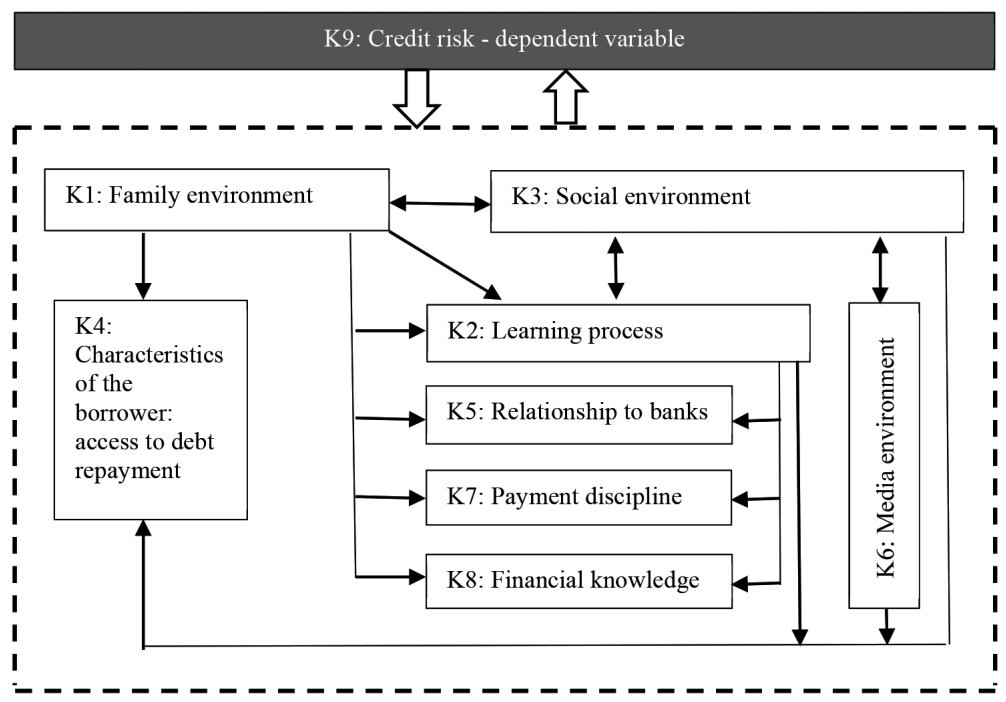

Figure 1. Causal relationship between credit risk management and social and economic factors

(source: Own processing)

The research brings interesting research findings and it also provides significant initiatives for further researches in this particular area in spite of its limitations that were especially presented by authors when formulating research materials and applications of methodological processes.

\section{Methodology}

The survey was conducted in the SME business environment in the Czech Republic in 2017. The interviewed were entrepreneurs and managers of selected SME in the form of questioning. Research material was designed to expose entrepreneurs' relationships to credit risk and its determinants.

Based on a study of professional and scientific literature, as well as expert meetings 9 areas were profiled in the context of fulfillment of research objective, in which a specific research constructs (factor $\mathrm{K}$ ) and their qualitative characteristics were defined (statements $\mathrm{Kxx}$ ):

- No. 1 - Family education in the field of finance has shaped correct attitudes;

- No. 2 - Acquired knowledge in education;

- No. 3 - Social perceptions of indebtedness in society;

- No. 4 - Characteristics linked to business;

- No. 5 - The relationship of the entrepreneur with banking institutions that provide credit products;

- No. 6 - The impact of the media environment on the perception of corporate credit risk;

- No. 7 - Financial environment in the SME segment;

- No. 8 - Financial literacy of entrepreneurs in the area of capital;

- No. 9 - Corporate credit risk management. 
Factors K1 to K9 are streamlined in Table 1. Logical linking of research hypotheses (H1H8) is also evident.

Table 1. Examined constructs $(\mathrm{K})$ and the quality characteristics $(\mathrm{Kxx})$ (source: own processing)

\begin{tabular}{|l|}
\hline \multicolumn{1}{|c|}{ Item and its definition } \\
\hline K1: The family environment shapes the entrepreneur's right approach to managing credit risk H1 \\
\hline \\
K11: I have received useful tips in the family about how to manage money. \\
\hline K12: My parents advised me to make money. \\
\hline K13: In my family, there is a positive perception of business loans. \\
\hline K14: It is necessary to create a financial reserve in business. \\
\hline
\end{tabular}

K2: The education process forms the right approach for the entrepreneur to manage credit risk $\mathrm{H} 2$

K21: I learned how to use money in my life at school.

K22: I learned a lot about the money that helps me in business.

K23: The education system generally provides good insights into how to work with money.

K24: With the education system, I understand corporate finance (what is the economic result, what are the sources of financing the company and the risks of financing, which is credit risk).

K3: The social environment forms the right approach for the entrepreneur to manage credit risk $\mathrm{H} 3$

K31: The company sees the indebtedness of companies positively.

K32: The company understands that loans are helping business.

K33: In the company prevails the view of no possible business without the use of loans.

K34: The social environment positively assesses investment in credit-backed companies.

K4: Personal qualities of the entrepreneur form the right approach to managing credit risk $\mathrm{H} 4$

K41: The most important characteristic of the entrepreneur is the risk aversion.

K42: The most important feature of the entrepreneur is responsibility.

K43: The most important characteristic of the entrepreneur is perseverance.

K44: The most important prerequisite for successful entrepreneurs is their expertise.

K5: The entrepreneur's relationship with banks shapes its right approach to managing credit risk H5

K51: Banks help entrepreneurs reach their financial goals.

K52: Bank lending conditions are acceptable to business owners.

K53: Bank lending conditions are transparent to business owners.

K54: Credit prices are good for us.

K6: The media environment shapes the entrepreneur's right approach to managing credit risk H6

K61: From the media environment, positive signs of entrepreneurship support come from commercial banks.

K62: The media report that entrepreneurs have good opportunities to raise bank loans.

K63: The media informs appropriately about the problems of loan repayment companies.

K64: The media are well aware of the fact that taking a loan from a bank brings certain risks to entrepreneurs.

K7: Payment discipline in the business environment forms the right approach for the entrepreneur to manage credit risk $\mathrm{H} 7$ 
End od Table 1

\begin{tabular}{|l|l|}
\hline \multicolumn{2}{|c|}{ Item and its definition } \\
\hline \multicolumn{1}{|l|}{$\begin{array}{l}\text { K71: Financial discipline in the SME environment is good, business partners are paying in } \\
\text { agreed deadlines. }\end{array}$} \\
\hline K72: I consider it important to pay on time my commitments. \\
\hline K73: I always pay my obligations on time. \\
\hline K74: My business partners always pay me on time. \\
\hline $\begin{array}{l}\text { K8: Financial knowledge in the area of capital shapes the entrepreneur's right approach to } \\
\text { managing credit risk H8 }\end{array}$ \\
\hline $\begin{array}{l}\text { K81: Foreign capital (bank loan) is cheaper than the entrepreneur's equity and therefore, } \\
\text { I am using a bank loan. }\end{array}$ \\
\hline $\begin{array}{l}\text { K82: Foreign capital (bank loan) is less risky than the entrepreneur's equity and therefore, } \\
\text { I borrow money from the bank. }\end{array}$ \\
\hline $\begin{array}{l}\text { K83: Businesses need a certain amount of credit, but I think the entrepreneur should have more } \\
\text { equity than credit. }\end{array}$ \\
\hline K84: Foreign capital should be used primarily to finance the company's current capital. \\
\hline K9: Employee's ability to effectively manage credit risk (dependent variable) \\
\hline & K91: I understand the most important aspects of credit risk. \\
\hline K92: I can properly manage the credit risk in my business. \\
\hline K93: I know banks' requirements for managing credit risk (credit terms, credit security). \\
\hline K94: The most important source of repayment is the profit. \\
\hline
\end{tabular}

\subsection{Research process and sample description}

For research purposes, businesses from the Albertina database, covering the scope of all the SME businesses in the Czech Republic were selected. The selection of the addressed companies was carried out by using a random selection method. The sample comprised 352 businesses (58\% success rate of business addresses) which provided a feedback. Statistical data were collected from all 14 regions of the Czech Republic. The structure of the socio-demographic characteristics of the addressed entrepreneurs was as follows: males 265 (75.4\%), females 87 (24.6\%), university education 171 (48.6\%), secondary education with a graduation 139 (39.5\%), secondary education without maturity 42 (11.9\%). The structure of enterprises was as follows: enterprises up to 10 employees 233 (66.2\%), up to 50 employees $67(19.0 \%)$, up to 250 employees 52 (14.8\%). Within the surveyed enterprises, 227 enterprises $(64.5 \%)$ performed business activities for more than 10 years, 64 (18.2\%) from 5 to 10 years, and $61(17.3 \%)$ within 5 years. The survey was dominated by a number of business sectors: 130 enterprises (36.9\%), trade 90 (25.6\%), 63 (17.9\%), construction $44(12.5 \%)$, agriculture 14 (4.0\%). The questionnaire for managers and entrepreneurs of the SME consisted of 6 sociodemographic characteristics of enterprises (region of activity, business sector, and number of years of entrepreneurship, size of enterprise, gender and highest entrepreneurship education) and of 36 claims related to credit risk. The method of structural equation modeling (SEM) is the supporting analytical method chosen in the context of achieving the research objective. Its application advantage lies above all in the ability to detect and accurately explain rela- 
tionships between indicators (latent unobserved variables) that originally do not explain the same factor examined. In the case of the research problem, the resulting model of structural equations enables to create a hierarchical structure of factors determining the perception of credit risk and also to determine relationships between factors by means of several indicators (Olsson, Foss, Troye, \& Howell, 2000). This graphical interface platform was created, providing the ability to present both table and graph results. By testing statistical hypotheses in the form of theoretical models (Hancock \& Mueller, 2013), quantitative expressions of their relationships were verified in individual research steps.

The entire research process consists of several phases, which are explained in the following subchapter.

\subsection{Creating a model}

Business research on credit risk was conducted through the evaluation of indirectly observable variables - latent constructs (Babin, Hair, \& Boles, 2008). For each latent variable, formulated statements were made to capture the attitudes of entrepreneurs. The arguments allowed the presence of the qualitative dimension of the basic latent variables. Importance and size of basic latent variables (arguments ratio of latent variables was $4: 1$ ). The data were evaluated by the SPSS and AMOS statistical software. The assumptions for testing the use of the SEM method (Wallenburg \& Weber, 2005) in the form of the multidimensional normality of the data and the size of the sample were confirmed. At the beginning of the research, nine latent variables were identified and called as factors. There were 4 statements available for each factor (indicators from No. 11, No. 12, No. 13, No. 14 (Factor No. 1), ... No. 91, No. 92, No. 93, No. 94 (Factor No. 9)). The Likert Scale (Schreiber, Nora, Stage, Barlow, \& King, 2006) with five levels of responses was used to evaluate the assertions, using exploratory factor analysis to verify all factors of analysis (Noriss \& Lecavalier, 2009) via the use of minimal estimation residuals. After finding dependencies between variables (correlation matrix), the optimal number of identified factors using the very simple structure (VSS) was determined (Shah \& Goldstein, 2006). The result obtained by the VSS method was as follows: for complexity 1 there are 8 factors, for complexity 2 the maximum number in the range of 8 to 13 factors. The number of factors by comparing models based on the Bayesian information criterion (BIC) (Wit, Heuvel, \& Romeijn, 2012), resulting in a model containing 8 factors. The results obtained were satisfactory given the number of defined factors at the beginning of the research. At the end, EFA's 8-factor method was applied. The technique of orthogonal rotation (Varimax) was used to interpret factor matrices (Hair, Anderson, Babin, \& Black, 2010). If the results of the iterative process of the indicators showed a lower commonality of high cross-loads $(>|0.3|)$ and single-factor loads $(>|0.1|)$, then they were deleted. The squared factor loading is the communality estimate for a variable. The communality measures the percent of variance in a given variable explained by its latent variable (indicators) and may be interpreted as the reliability of the indicator. To investigate possible effects of consequent analysis and reliability estimates, rotated factor loadings were used (Eisinga, Grotenhuis, \& Pelzer, 2012). With Cochrane Alpha per 1000 bootstrapped samples, factor reliability was estimated. It expresses the ratio between the model variability of the evaluation and the actual variability of the explanatory factor. 


\section{Analysis and findings}

Table 2 presents the best solution to meet our face validity requirement. The factor load of the indicator was specified in order to verify if the absolute value was greater than 0.3 . The results show that the factors explained $47.1 \%$ of the total scatter of the rating. The values of the factor loading indicators reached by the technique oblique factor rotation were slightly different, but insignificant. Factors were constructed using the same indicators. In the table, they are sorted according to the amount of scattering of the source file they explain.

Table 2. Results of factor load on indicators, reliability and communality (source: own processing)

\begin{tabular}{|c|c|c|c|c|c|c|c|c|c|}
\hline \multirow{2}{*}{ Indicators } & \multicolumn{8}{|c|}{ Factors determining the business environment } & \multirow{2}{*}{$\begin{array}{c}\text { Commu- } \\
\text { nality }\end{array}$} \\
\hline & K2 & K5 & K8 & K4 & K9 & K7 & K1 & K6 & \\
\hline K22 & 0.807 & & 0.384 & & & & & & 0.704 \\
\hline K24 & 0.756 & & & 0.306 & 0.380 & 0.375 & & 0.398 & 0.627 \\
\hline K21 & 0,736 & & & & & 0.331 & & & 0.638 \\
\hline $\mathrm{K} 23$ & 0.624 & & 0.374 & & 0.305 & 0.339 & 0.304 & & 0.543 \\
\hline K52 & 0.354 & 0.754 & & & & & & & 0.708 \\
\hline K54 & & 0.661 & & & & 0.331 & & & 0.640 \\
\hline K32 & 0.351 & 0.529 & & & & 0.319 & 0.334 & & 0.424 \\
\hline K51 & & 0.524 & & 0.327 & 0.320 & & 0.385 & 0.389 & 0.479 \\
\hline K53 & & 0.477 & & 0.330 & & & 0.354 & & 0.444 \\
\hline K82 & & & 0.773 & & & & & & 0.642 \\
\hline K81 & & 0.360 & 0.708 & & & & 0.392 & 0.320 & 0.668 \\
\hline K13 & 0.312 & & 0.556 & & & & & & 0.517 \\
\hline K42 & & & & 0,69 & & & & & 0.573 \\
\hline K44 & & & & 0,643 & & 0.394 & & & 0.451 \\
\hline K43 & & & & 0,593 & & & & & 0.456 \\
\hline K41 & & & 0.303 & 0,474 & & 0.396 & & & 0.439 \\
\hline K91 & & & & & 0.751 & & & & 0.613 \\
\hline K92 & & 0.324 & & & 0.675 & & 0.302 & & 0.502 \\
\hline K93 & & & 0.333 & & 0.665 & & 0.321 & 0.386 & 0.437 \\
\hline K72 & & 0.487 & & & & 0.744 & 0.341 & 0.344 & 0.575 \\
\hline K73 & & & & & & 0.732 & & & 0.627 \\
\hline K14 & & & & 0.360 & & 0.582 & 0.334 & & 0.461 \\
\hline K11 & 0.309 & & & & & & 0.756 & & 0.615 \\
\hline K12 & & 0.316 & 0.343 & 0.352 & & & 0.625 & & 0.504 \\
\hline K62 & & & & & & & & 0.705 & 0.588 \\
\hline K61 & & & 0.363 & & & & 0.332 & 0.665 & 0.539 \\
\hline $\begin{array}{l}\text { Cumulative } \\
\text { Variance }\end{array}$ & 12.1 & 20.1 & 26.3 & 31.7 & 36.1 & 40.3 & 44.0 & 47.1 & \\
\hline Reliability & 0.765 & 0.675 & 0.638 & 0.541 & 0.608 & 0.598 & 0.557 & 0.494 & \\
\hline
\end{tabular}

Explanatory notes: Factor load on the indicator is given if its absolute value is higher than 0.3 . 
The results in Table 2 show that $\mathrm{K} 1, \mathrm{~K} 2, \mathrm{~K} 4, \mathrm{~K} 5, \mathrm{~K} 7, \mathrm{~K} 8, \mathrm{~K} 9$ are identified in the company in addition to the factor K3 - social perception of indebtedness. Factor K2 - gained knowledge in the context of entrepreneurship education - was identified as the most important, because it reached the highest value of reliability, while explaining the largest relative share of total scattering. This factor consists of four indicators. The number of indicators in that factor is not large, which improves the reliability value. The factors K7, K8 and K9 have the same three indicators. Factors K1 and K6 include only two indicators. These factors have weaker confidence values (K1: 0.557 and K6: 0.494). These results have an impact on SEM route estimation. In order to avoid too optimistic results, the strength of the directional path was reduced. For the above-mentioned reasons, the K6 factor - the impact of the media environment on perceived corporate credit risk - was not used in the further testing or in the presentation of the structural model. It is expected that the factor $\mathrm{K} 1$ - family environment entrepreneur - can have a mutual bond in the form of covariance with the characteristics of an entrepreneur binding to its business, which is a factor K4.

The factor variances value was set at 1 . Figure 2 shows two covariance relationships among the factors related to banking (between $\mathrm{K} 5$ and $\mathrm{K} 8$, path coefficient $=0.670$ ) and between the family environment and the entrepreneurial characteristics of entrepreneurs (between $\mathrm{K} 1$ and $\mathrm{K} 4$, path coefficient $=0.62$ ). The following characteristics were used to evaluate the fit model: chi-squared test, rooted mean square error of approximation (RMSEA),

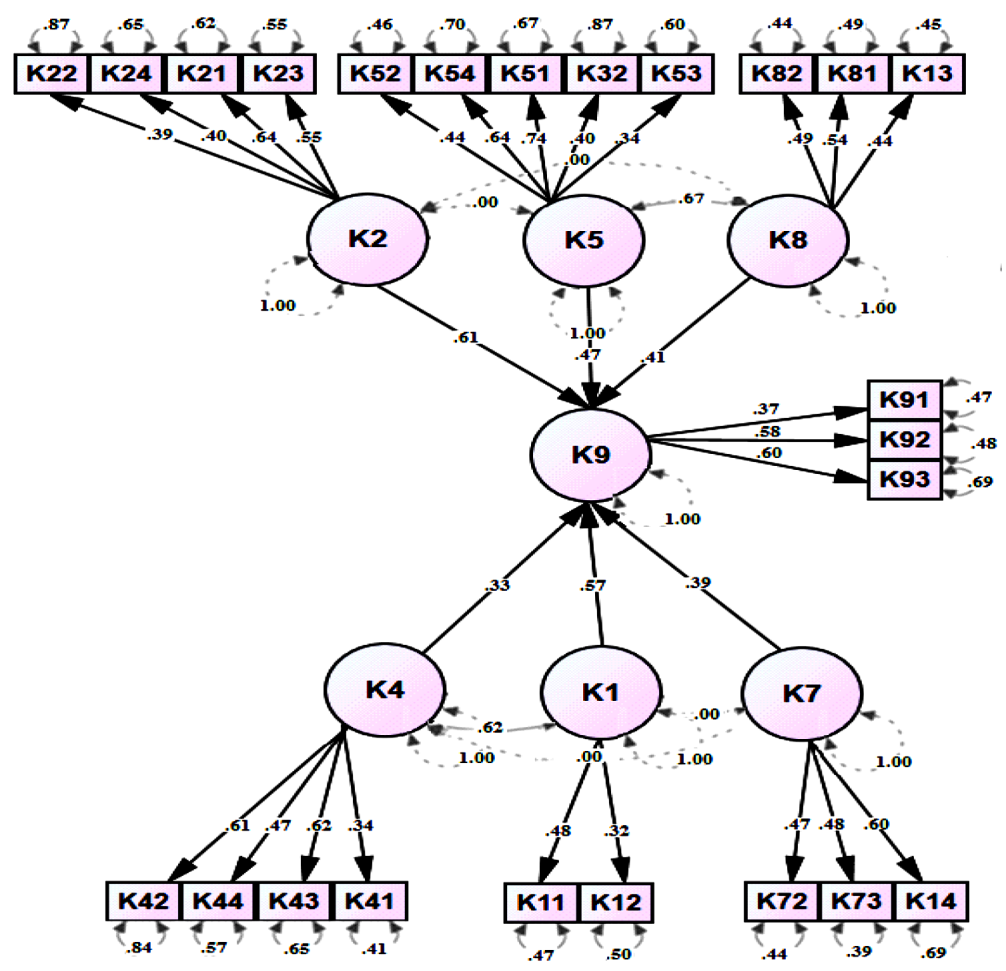

Figure 2. Structured model with standardized path estimates (source: own processing) 
standardized root mean residual (SRMR) and comparative fit index (CFI) (Martínez-López, Gázquez-Abad, \& Sousa, 2013). The results are shown in Table 3.

Table 3. Results of the characteristics of Fit model source: own processing

\begin{tabular}{|l|c|}
\hline \multicolumn{1}{|c|}{ Characteristics of Fit model } & Test value \\
\hline Chi-squared test & $\begin{array}{c}471.746 \\
\end{array}$ \\
\hline RMSEA & $(\mathrm{df}=100, \mathrm{p}$-value $<0.01)$ \\
\hline SRMR & 0.048 \\
\hline CFI & 0.0794 \\
\hline
\end{tabular}

The results of the test statistics of the examined model point to the fact that at the significance level of 0.05 there is a difference between the observed covariance matrix and the model covariance matrix. This result is favorable to the size of the sample (352 entrepreneurs). The CFI indicates the quality of fit on the border (0.9). This CFI is affected by the average correlation magnitude in the data. Absolute fit characteristics (RMSEA and SRMR) achieve satisfactory results with respect to sample size. Corporate credit risk management of the SME has the greatest impact on entrepreneurship education $(\mathrm{H} 2$, path coefficient $=0.61$, $\mathrm{p}$-value $<0.01$ ). Entrepreneurs who have a positive attitude towards banking institutions tend to be more positive about the risk (credit risk is manageable). The factors $\mathrm{K} 1, \mathrm{~K} 2, \mathrm{~K} 5, \mathrm{~K} 7$, K8 affect the credit risk to a lesser extent, but they have an equally oriented relationship. The coefficient path values are shown in Figure 2. The hypotheses H1, H2, H3, H4, H5 and H6 were accepted. The structural model has confirmed that there is a correlation between the factors: the direct relationship ( $\mathrm{H} 7$, path coefficient $=0.67, \mathrm{p}$-value $<0.01$ ). There is also a correlation between: the characteristics and family background of the entrepreneur $(\mathrm{H} 8$, path coefficient $=0.62$, p-value $<0.01$ ). The structural model confirmed an undirected relationship between: bank factors and social perceptions of indebtedness in the company (H9, path coefficient $=0.00$, p-value $=0.01$ ). For more clarity in the structural model, not all non-oriented relationships are listed.

\section{Conclusion and implications}

The aim of the article was to create a causal model to examine the relationships between the credit risk factor and its economic and social determinants specific to the SME business environment and to quantify these links.

The research findings show that the most significant link in the structural model was factor K2 expressing education. This is also explained by the fact that the ability to effectively manage credit risk in a firm is greatly influenced by the knowledge acquired by the entrepreneur in an educational process geared to the correct use of money in life. Financial knowledge of entrepreneurs is clearly related to the level of financial literacy. An insufficient level has significant economic and social impacts, both short-term and long-term (Szovics, 2012; Lusardi, 2014). From the macroeconomic point of view, financial literacy is also con- 
tributing to the deepening of the financial crisis, people are losing orientation in the products offered by financial institutions, their financial decisions are very risky and many times they turn into existential problems (Vravec, 2014; Rutledge, 2010). This negative aspect can also be converted into the financial behavior and decision-making of the entrepreneur under the terms of his company. Financial literacy should be explored within approaches that prefer rationality and pragmatic considerations, as well. Foreign research studies state that higher financial knowledge helps individuals to monitor optimal consumption and balanced financial portfolios (Romiti \& Rossi, 2014) and also leads to greater likelihood of savings and proper financial planning over a long-term horizon (Fernandéz-López, Otero, Vivel, \& Rodeiro, 2010; Hung, Parker, \& Yoong, 2009).

The second most important factor determining the ability of an entrepreneur to effectively manage credit risk in a company is the family environment. This environment creates a platform for gaining useful advice over an individual's life, such as managing money (K11) and raising money (K12). Another factor identified as the most important factor was the relationship of entrepreneurs to banks, which is of an economic nature and includes integrated experience of co-operation with banks in the credit financing of companies. The financial knowledge factor in the capital field has a lesser impact on the formation of effective entrepreneurs' approach to managing credit risk. The results clearly state that entrepreneurs do not have good knowledge of capital management, as only $31 \%$ of them agree with the claim that foreign capital is cheaper than equity capital, or foreign capital is less risky than equity (only $18 \%$ of the total number of entrepreneurs agreed to this claim). The claim that the entrepreneur should have a larger volume of equity was agreed by up to $72 \%$ of entrepreneurs. Only $32 \%$ of entrepreneurs were of the opinion that foreign capital should be used to finance the company's current assets. Economic factor meaning the payment discipline also had less impact on the formation of effective entrepreneurs' approach to managing credit risk. K14 was identified as the most important indicator, which means that entrepreneurs in the context of insolvency stressed the need to create financial reserves. $40 \%$ of entrepreneurs agree with the claim that business partners adhere to the payment discipline. As far as results related to the entrepreneurial characteristics of entrepreneurs are concerned, entrepreneurs most prefer responsibility (88\%), endurance (77\%), expertise (65\%) and ultimately risk aversion (only $26 \%$ ).

From a conceptual point of view, a structural model providing a wide range of results explained about $47.1 \%$ of the overall variability of the assertion assessment. These findings have provided a platform for follow-up research in identifying other related factors affecting credit risk management in the SME as well as in the process of deeper exploration of the relationships found and their socio-economic implications.

Apart from the benefits in research areas, there are clear benefits in the study also for practice. In conclusion, the results stated in the present study will outline a better picture of the impact of different determinant groups on managing the SME's credit risk, especially for policy-makers as well as experts in the development of regional and national strategic plans, to streamline the creation of concepts aimed at more active support for the business environment in the SME segment in the Czech Republic and the elimination of regional disparities and discrepancies. Generalizing these outcomes may result in averaging the results 
related to supporting the SME's development, which may have fatal consequences for their further development and the development of their competitiveness. In addition to the above mentioned possibilities, the usefulness of the research results in the processes of development and improvement of the methodologies for detection and quantification of the links between the socio-economic determinants in the system stating soft data and the creation of a platform for national and international benchmarking may be evident. These processes can ultimately encourage higher research efforts in this area by specific research teams and their support by the state, as well.

\section{Disclosure statement}

The authors do not have any competing financial, professional, or personal interests from other parties.

\section{References}

Babin, B. J., Hair, J. F., \& Boles, J. S. (2008). Publishing research in marketing journals using structural equation modeling. The Journal of Marketing Theory and Practice, 16(4), 279-286. https://doi.org/10.2753/MTP1069-6679160401

Beck, T., Degryse, H., De Haas, R., \& Van Horen, N. (2015). When arm's length is too far: Relationship banking over the credit cycle. Systematic Risk Centre. Discussion Paper No 33.

Beck, T., \& Demirguc-Kunt, A. (2006). Small and medium-size enterprises: Access to finance as a growth constraint. Journal of Banking \& Finance, 30(11), 2931-2943. https://doi.org/10.1016/j.jbankfin.2006.05.009

Berger, A. N., \& Udell, G. F. (2006). A more complete conceptual framework for SME finance. Journal of Banking \& Finance, 30(11), 2945-2966. https://doi.org/10.1016/j.jbankfin.2006.05.008

Bruns, V., \& Fletcher, M. (2008). Banks' risk assessment of Swedish SMEs. Venture Capital, 10(2), 171194. https://doi.org/10.1080/13691060801946089

Corazza, M., Funari, S., \& Gusso, R. (2016). Creditworthiness evaluation of Italian SMEs at the beginning of the 2007-2008 crisis: An MCDA approach. The North American Journal of Economics and Finance, 38, 1-26. https://doi.org/10.1016/j.najef.2016.05.008

Dierkes, M., Erner, C., Langer, T., \& Norden, L. (2013). Business credit information sharing and default risk of private firms. Journal of Banking \& Finance, 37(8), 2867-2878. https://doi.org/10.1016/j.jbankfin.2013.03.018

Eggers, F., Kraus, S., Hughes, M., Laraway, S., \& Snycerski, S. (2013). Implications of customer and entrepreneurial orientations for SME growth. Management Decision, 51(3), 524-546. https://doi.org/10.1108/00251741311309643

Eisinga, R., Grotenhuis, M., \& Pelzer, B. (2012). The reliability of a two-item scale: Pearson, Cronbach, or Spearman-Brown? International Journal of Public Health, 58(4), 637-642. https://doi.org/10.1007/s00038-012-0416-3

European Commission. (2016). SME Performance Review 2015/2016. Retrieved from http://ec.europa. eu/growth/smes/business-friendly-environment/performance-review-2016_en\#annual-report

European Union. (2016). SBA Fact Sheet, European Commission Directorate-General for Internal Market, Industry, Entrepreneurship and SMEs. Brussels. 
Fairlie, R. W., \& Holleran, W. (2012). Entrepreneurship training, risk aversion and other personality traits: Evidence from a random experiment. Journal of Economic Psychology, 33(2), 366-378. https://doi.org/10.1016/j.joep.2011.02.001

Fernandéz-López, S., Otero, L., Vivel, M., \& Rodeiro, D. (2010). What are the driving forces of individuals' retirement savings? Finance a Uver - Czech Journal of Economics \& Finance, 60(3), 226-251.

Fredriksson, A., \& Moro, A. (2014. Bank-SMEs relationships and banks' risk-adjusted profitability. Journal of Banking \& Finance, 41, 67-77. https://doi.org/10.1016/j.jbankfin.2013.12.026

Grunert, J., Norden, L., \& Weber, M. (2005). The role of non-financial factors in internal credit ratings. Journal of Banking \& Finance, 29(2), 509-531. https://doi.org/10.1016/j.jbankfin.2004.05.017

Hair, J. F., Anderson, R. E., Babin, B. J., \& Black, W. C. (2010). Multivariate data analysis: A global perspective ( $7^{\text {th }}$ ed.). Upper Saddle River, NJ: Pearson Prentice Hall.

Hancock, G. R., \& Mueller, R. O. (Eds.) (2013). Structural equation modeling: A second course, Quantitative methods in education and the behavioral sciences: Issues, research, and teaching. Charlotte NC: Information Age Publishing.

Hung, A., Parker, A. M., \& Yoong, J. (2009). Defining and measuring financial literacy. Working paper WR-708, RAND corporation. https://doi.org/10.2139/ssrn.1498674

Irwin, D., \& Scott, J. M. (2010). Barriers faced by SMEs in raising bank finance. International Journal of Entrepreneurial Behavior \& Research, 16(3), 245-259. https://doi.org/10.1108/13552551011042816

Kozubíkova, L., Belas, J., Bilan, Y., \& Bartos, P. (2015). Personality characteristics of entrepreneurs in the context of perception and management of business risks in the SME segment. Economics and Sociology, 8(1), 41-54. https://doi.org/10.14254/2071-789x.2015/8-1/4

Kozubíkova, L., Homolka, L., \& Kristalas, D. (2017). The effect of business environment and entrepreneurs' gender on perception of financial risk in the smes sector. Journal of Competitiveness, 9(1), 36-50. https://doi.org/10.7441/joc.2017.01.03

Kremp, E., \& Sevestre, P. (2013). Did the crisis induce credit rationing for French SMEs?. Journal of Banking \& Finance, 37(10), 3757-3772. https://doi.org/10.1016/j.jbankfin.2013.05.028

Kundid, A., \& Ercegovac, R. (2011). Credit rationing in financial distress: Croatia SMEs' finance approach. International Journal of Law and Management, 53(1), 62-84.

https://doi.org/10.1108/17542431111111890

Lazányi, K. (2014). Entrepreneurs of the future. Serbian Journal of Management, 9(2), 149-158. https://doi.org/10.5937/sjm9-6257

Li, K., Niskanen, J., Kolehmainen, M., \& Niskanen, M. (2016). Financial innovation: Credit default hybrid model for SME lending. Expert Systems with Applications, 61, 343-355.

https://doi.org/10.1016/j.eswa.2016.05.029

Lusardi, A. (2014). Financial literacy and ignorance: financial literacy highlights of 2014: The PISA data. Retrieved from http://annalusardi.blogspot.sk/search?updated-max=2015-01-10T17:50:0005:00\&max-results $=7 "$ max-results $=7$

Martínez-López, F. J., Gázquez-Abad, J. C., \& Sousa, C. M. P. (2013). Structural equation modelling in marketing and business research. European Journal of Marketing, 47(1/2), 115-152. https://doi.org/10.1108/03090561311285484

Mohelska, H., \& Sokolova, M. (2016). Smart, connected products change a company's business strategy orientation. Applied Economics, 48(47), 4502-4509. https://doi.org/10.1080/00036846.2016.1158924

Neuberger, D., \& Räthke-Döppner, S. (2014). The role of demographics in small business loan pricing. Small Business Economics, 44(2), 411-424. https://doi.org/10.1007/s11187-014-9602-4

Norris, M., \& Lecavalier, L. (2009). Evaluating the use of exploratory factor analysis in developmental disability psychological research. Journal of Autism and Developmental Disorders, 40(1), 8-20. https://doi.org/10.1007/s10803-009-0816-2 
Olsson, U. H., Foss, T., Troye, S. V., \& Howell, R. D. (2000). The performance of ML, GLS, and WLS estimation in structural equation modeling under conditions of misspecification and nonnormality. Structural Equation Modeling: A Multidisciplinary Journal, 7(4), 557-595. https://doi.org/10.1207/S15328007SEM0704_3

Psillaki, M., \& Eleftheriou, K. (2014). Trade credit, bank credit, and flight to quality: Evidence from French SMEs. Journal of Small Business Management, 53(4), 1219-1240. https://doi.org/10.1111/jsbm.12106

Romiti, A., \& Rossi, M. (2014). Wealth decumulation, portfolio composition and financial literacy among European elderly (No. 375). Collegio Carlo Alberto.

Rutledge, S. L. (2010). Consumer protection and financial literacy: Lessons from nine country studies. Policy Research working paper (5326). Washington, DC: World Bank. Retrieved from http://documents.worldbank.org/curated/en/676251468233092150/Consumer-protection-and-financial-literacy-lessons-from-nine-country-studies

https://doi.org/10.1596/1813-9450-5326

Schreiber, J. B., Nora, A., Stage, F. K., Barlow, E. A., \& King, J. (2006). Reporting structural equation modeling and confirmatory factor analysis results: A review. The Journal of Educational Research, 99(6), 323-338. https://doi.org/10.3200/JOER.99.6.323-338

Shah, R., \& Goldstein, S. M. (2006). Use of structural equation modeling in operations management research: Looking back and forward. Journal of Operations Management, 24(2), 148-169. https://doi.org/10.1016/j.jom.2005.05.001

Slavec, A. (2014). Bank financing and trade credit use of Slovenian small firms: An empirical examination. Transformations in Business and Economics, 13(2), 91-101.

Sobekova Majkova, M. (2016). The Relationship between the risk of a change of the interest rate and the age of entrepreneurs among Slovak SMEs. Journal of Competitiveness, 8(3), 125-138. https://doi.org/10.7441/joc.2016.03.08

Sokolová, M., Mohelská, H., \& Zubr, V. (2016). Pay and offer of benefits as significant determinants of job satisfaction - a case study in the Czech Republic. E+M Ekonomie a Management, 19(1), 108120. https://doi.org/10.15240/tul/001/2016-1-008

Szovics, P. (2012). Quo vadis finančné vzdelávanie?. Biatec. 20(1). Retrieved from http://www.nbs.sk/ sk/publikacie/biatec-odborny-bankovy-casopis/rocnik-2012/biatec-c-1-201

Vos, E., Yeh, A. J.-Y., Carter, S., \& Tagg, S. (2007). The happy story of small business financing. Journal of Banking \& Finance, 31(9), 2648-2672. https://doi.org/10.1016/j.jbankfin.2006.09.011

Vravec, J. (2014). Analýza úrovne finančnej gramotnosti a finančnej situácie obyvatelov východného Slovenska Derivat, 4. Retrieved from http://www.derivat.sk/index.php?PageID=2346

Wallenburg, C. M., \& Weber, J. (2005). Structural equation modelling as a basis for theory development within logistics and supply chain management research. In H. Kotzab, S. Seuring, M. Muller, G. Reiner (Eds.), Research methodologies in supply chain management (pp. 171-186). Heidelberg: Physica. https://doi.org/10.1007/3-7908-1636-1_12

Wang, Y. (2016). What are the biggest obstacles to growth of SMEs in developing countries? - An empirical evidence from an enterprise survey. Borsa Istanbul Review, 16(3), 167-176. https://doi.org/10.1016/j.bir.2016.06.001

Wit, E., Heuvel, E. van den, \& Romeijn, J. W. (2012). "All models are wrong...”: An introduction to model uncertainty. Statistica Neerlandica, 66(3), 217-236. https://doi.org/10.1111/j.1467-9574.2012.00530.x

Yahaya, S. N., Mansor, N., \& Bakar, M. H. (2016). Credit risk model: The conceptual framework of SME financing. International Journal of Research and Reviews in Applied Sciences, 26(2). Retrieved from www.arpapress.com/Volumes/Vol26Issue3/IJRRAS_26_3_02.pdf 